\title{
18. Aural Snapshots of Musical Life: The 1948 recordings
}

\author{
Linda Barwick and Allan Marett \\ In memory of our friend Kenny Burrenjuck, 1950-2008
}

In the original proposal for the 1948 American-Australian Scientific Expedition to Arnhem Land made by Charles Mountford to the National Geographic Society, the fourth proposed study area (after bark painting, body painting and general ethnology) was 'music in secular and ceremonial life', with the note: 'the recording of Aboriginal songs if equipment is available.' ${ }^{1}$ As it turned out, with the involvement of the Smithsonian Institution and the Australian Commonwealth Government, the majority of personnel on the Arnhem Land Expedition came from scientific disciplines, rather than the humanities (see May, this volume). Although Mountford himself did significant research on bark paintings and ethnology (as reported in Volume 1 of the Expedition records), ${ }^{2}$ the planned focus on songs became rather neglected, partly because Mountford's own research interests and expertise lay elsewhere, and partly because there were apparently problems with the Expedition's recording equipment, which meant that he was unable to record after Groote Eylandt, the first official stop on the Expedition. It appears that no sound recordings were made at Yirrkala, the Expedition's second stop. At Oenpelli (now Gunbalanya), the third stop, Colin Simpson from the Australian Broadcasting Commission (now Corporation; $\mathrm{ABC}$ ) with recordist Ray Giles visited the Expedition camp and made a feature radio program, along with a number of sound recordings, which were drawn on by Mountford in the official published recordings of the Expedition. ${ }^{3}$ (For further discussion of Simpson, see MacGregor, this volume.)

A review of the published and unpublished audiovisual recordings associated with the Expedition reveals that a substantial proportion of them did not emanate from any of the three official Expedition locations; rather, they were of performers then resident at Delissaville (now Belyuen), a government settlement established in the 1940s on the Cox Peninsula, on the southern side of Darwin Harbour.

\footnotetext{
1 C. P. Mountford, Application to Chairman of the Research Committee, National Geographic Society, 5 March 1945, Correspondence 1945-49, vol. 1 1945-47, American/Australian Scientific Expedition to Arnhem Land 1948 Records, PRG 1218/17/4, Mountford-Sheard Collection, State Library of South Australia (hereafter SLSA), Adelaide.

2 Mountford, C. P. (ed.) 1956, Records of the American-Australian Scientific Expedition to Arnhem Land. Volume 1: Art, myth and symbolism, Melbourne University Press, Carlton, Vic.

3 Simpson, C. 1948, Expedition to Arnhem Land, Radio Feature, first broadcast 30 November 1948, Australian Broadcasting Commission, Sydney; Mountford, C. P. 1949, American-Australian Scientific Expedition to Arnhem Land 1948, (nine 78 rpm discs), Australian Broadcasting Commission, Sydney.
} 
Both Mountford and Simpson visited Delissaville on separate occasions in 1948: Mountford, along with most of the other Expedition members, in March, before the Expedition proper set out for Groote Eylandt; and Simpson later in the year, after he had visited Oenpelli in September. ${ }^{4}$ Delissaville performers might also have been recorded by Expedition members elsewhere: silent colour-film footage taken by the National Geographic Society's Howell Walker shows identifiable Delissaville dancers apparently performing for a non-Aboriginal audience in a location that could be Darwin's Botanical Gardens. ${ }^{5}$ Since Walker did not visit Delissaville with Mountford and other Expedition members in March 1948, it is possible that this footage was recorded during the brief break that Expedition members took in Darwin in the period 9-18 September 1948. ${ }^{6}$ Perhaps this was the same performance by dancers from Delissaville, Milingimbi and Melville Island in the Darwin Botanic Gardens witnessed by Simpson 'before we went into Arnhem Land'. ${ }^{7}$

We have used the term 'snapshots' in our title to evoke the idea of something intimately tied to a particular moment, yet incomplete - a partial record constrained by the time, place and means of its capture, inevitably representing only one point of view, or a few particular details of a more complex phenomenon. Like a series of snapshots, these few audiovisual recordings need contextualising, with metadata to name their subjects and their provenance, linking them to each other and to other records. While we acknowledge the aspirations of the recordists to present a true and authentic picture of Aboriginal musical life at the time, many questions are also raised. What did these aural snapshots actually represent? Why were particular groups present in these particular places and why were particular repertories performed?

Although some questions remain about the history of the recordings, this chapter will focus on the content of the Delissaville and Oenpelli material- the repertories and song genres recorded, their performers and their provenancewith a view to exploring what the compilation of these snapshots can tell us about musical life in the Top End of the Northern Territory at the time. Then, through close consideration of one event - a Kapuk (rag-burning) ceremony recorded by Simpson at Delissaville - we will reflect on the reliability of the interpretations placed on the event by its non-Aboriginal observers, and on the significance of the recording for present-day descendants of those recorded.

4 C. P. Mountford, 1948, Expedition to Arnhem Land, vol. 1, 1948, Personal Journal, PRG 1218/17/12, Mountford-Sheard Collection, SLSA; Simpson, C. 1949, Delissaville: Death rite for Mabalung, Radio Feature, first broadcast 15 March 1949, Australian Broadcasting Commission, Sydney; Simpson, C. 1951, Adam in Ochre: Inside Aboriginal Australia, Angus \& Robertson, Sydney.

5 Walker, H. (cine-photographer) 1950, Aboriginal Australia, (Lecture film), National Geographic Society, Washington, DC.

6 Mountford's diary for this period covers the break in Darwin but does not mention such a performance; nevertheless, the possibility that other Expedition members attended something similar cannot be excluded.

7 Simpson, Adam in Ochre, p. 135. 
First, we turn to an overview of the known sound recordings. As was normal practice at the time, original wire recordings were transferred to $78 \mathrm{rpm}$ discs for preservation and access purposes, and copies were distributed not only to the collector but also to various libraries in Australia and overseas. ${ }^{8}$ EMI Australia's Columbia Graphophone plant at Homebush, New South Wales, which processed location recordings for the $\mathrm{ABC}$ and other organisations, created a set of four 12-inch $78 \mathrm{rpm}$ discs under the title Groote Eylandt and Port Darwin Aboriginal Songs, Annotated by C. P. Mountford from Mountford's original wire recordings. ${ }^{9}$

The Groote Eylandt recordings (PRX2712-14) include approximately 30 minutes of music, covering 21 songs belonging to clans then resident on the west coast of Groote Eylandt whose traditional country included Bickerton Island (a smaller island west of Groote). These songs were recorded at Thompsons Bay, some 13 $\mathrm{km}$ from Umbakumba, where the Expedition was based. ${ }^{10}$ We will not discuss these songs further here. ${ }^{11}$

The disc of Port Darwin Aboriginal songs (PRX2715) includes six cuts. These songs were described in Mountford's personal journal on Sunday, 28 March 1948. Mountford noted: 'Today, we were able to get the wire recorder going, and record some of the songs of the Worgait, or, I understand, Worgaitja.' ${ }^{12}$

For the disc, Mountford recorded a brief introduction to each song, such as: 'This is a Worgait song chanted by Nilku and Gumbuduk. It is known as the Winmala song, and when it is sung it prevents the evil spirits from the bush from hurting the Aborigines in the camp.' ${ }^{13}$

Mountford's field notes were evidently used as the basis for this introduction, as the notes from 28 March demonstrate:

The second song was chanted by two men, Nilku, and Gumbuduk.

8 Ibid., p. 220. For further information about this practice, see Elkin, A. P. and Jones, T. 1958, Arnhem Land Music (North Australia), Oceania Monograph 9, University of Sydney, NSW, pp. 173-84; and Moyle, A. M. 1966, A Handlist of Field Collections of Recorded Music in Australia and Torres Strait, Australian Institute of Aboriginal Studies, Canberra.

9 Moyle, A Handlist of Field Collections of Recorded Music in Australia and Torres Strait, pp. 209-14; and Mountford, C. P. 1949, Groote Eylandt and Port Darwin Aboriginal Songs Annotated by C. P. Mountford, (four 12-inch discs, PRX2712-15), Columbia Graphophone, Homebush, NSW.

10 For more information on the circumstances surrounding this performance, see Thomas and Jones, this volume.

11 Mountford gives lengthy explanations and interpretations of some aspects of this restricted ceremony in the records of the Expedition. See Mountford, Records of the American-Australian Scientific Expedition to Arnhem Land, vol. 1.

12 Mountford, 1948, Personal Journal, vol. 1, pp. 87-93, PRG 1218/17/12, Mountford-Sheard Collection, SLSA.

13 Charles P. Mountford, Recorded introduction to PRX2715, Cut 2, 'The Winmala', transcribed by Linda Barwick, 2009. 
The song was known as Winmala. When it was chanted, it had the effect of keeping the evil spirits in the bush at bay, and thus protecting the camp. Some six weeks previously, the aborigines saw a light in the bush, which they attributed to a mythical serpent that moves about in the night and attacks and kills the people. ${ }^{14}$

We will have more to say about this particular song and its significance later in the chapter.

There is some confusion about the provenance of two further discs in this series, titled Oenpelli Aboriginal Songs (PRX2716-17). In her 1966 Handlist of Aboriginal and Torres Strait Islander music recordings, the musicologist Alice Moyle credited the discs to Colin Simpson, but in various library catalogues, including that of the State Library of South Australia's Mountford-Sheard Collection, they are credited to Mountford. ${ }^{15}$ As will be discussed below, although presented in a different order, all of the cuts on these discs can be matched with Simpson's Oenpelli recordings, four of which were published separately by Simpson as part of the 12-disc set Aboriginal Music from the Northern Territory of Australia, 1948, with Annotations by Professor A. P. Elkin (PRX2645-52 and PRX2708-11). ${ }^{16}$ Other recordings in this set came from Simpson's travels to Delissaville and Melville Island in the same year (which were made independently of the American-Australian Scientific Expedition to Arnhem Land). Very useful background information on the circumstances of Simpson's travels with Postmaster General's Department recordist Ray Giles can be found in Simpson's 1951 book, Adam in Ochre. ${ }^{17}$

Table 18.1 summarises the contents of this 12-disc publication by Simpson. For unknown reasons, the recordings are presented out of chronological order. In the table, we have grouped them into the three main locations, retaining the spelling used in Elkin's notes, with a transliteration into present-day orthography in square brackets where appropriate.

14 Mountford, 1948, Unpublished Field Notes, p. 87, SLSA. Another disc in the Mountford-Sheard Collection of the State Library of South Australia, PRG 1218/17/55, Aboriginal Songs of Delissaville, Oenpelli and Groote Eylandt, contains an edited selection of the sound recordings, possibly prepared for a lecture, which also seems to be paraphrased from Mountford's field notes. The explanations, in a woman's voice, include the following for side 1, track 5 (Winmala song): 'That was the song Winmala. This is a magical song, which has the effect of keeping the evil spirits in the bush from injuring the people in the camp during the hours of darkness. One of the Aborigines said that a few months previously the people in the camp saw a flickering light in the bush, which they attributed to a mythical serpent that was known to travel at night and will attack and kill people. On this occasion the whole tribe assembled in the ceremonial ground whilst the men chanted the Winmala. No-one was attacked' (transcribed by Linda Barwick, 2010).

15 Moyle, A Handlist of Field Collections of Recorded Music in Australia and Torres Strait, p. 211.

16 Simpson, C. 1949, Aboriginal Music from the Northern Territory of Australia, 1948, with Annotations by Professor A. P. Elkin, (twelve 12-inch discs, PRX2809-10, PRX2645-52), Australian Broadcasting Commission (processed by Columbia Graphophone), Sydney. Elkin himself visited Delissaville in 1946, 1949 and 1952, and published extensive notes about his recordings, supplemented by musical transcription and analysis by Trevor Jones. See Elkin and Jones, Arnhem Land Music; and Elkin, A. P. 1950, 'Ngirawat, or, the sharing of names in the Wagaitj tribe, northern Australia', in I. Tönnies (ed.), Beiträge zur Gesellungs- und Völkerwissenschaft, Gebrüder Mann, Berlin.

17 See Simpson, Adam in Ochre. 
Table 18.1 Summary contents of Simpson's 1948 recordings, sorted into rough chronological order

\begin{tabular}{|c|c|c|c|}
\hline Index & Singer or group & Song genre & Location recorded \\
\hline Side 1.1 & $\begin{array}{l}\text { Gunwinggu } \\
\text { [Kunwinjku] }\end{array}$ & $\begin{array}{c}\text { Jiwadja [lwaidja] sea } \\
\text { chant }\end{array}$ & Oenpelli \\
\hline Side 1.2 & 'Sam or Joshua' & $\begin{array}{l}\text { Gunbalang [Kun-barlang] } \\
\text { sweetheart song }\end{array}$ & Oenpelli \\
\hline Side 2.1 & Djauan [Jawoyn] & $\begin{array}{l}\text { Djauan [Jawoyn] trading } \\
\text { and sweetheart song }\end{array}$ & Near Oenpelli \\
\hline Side 2.2 & Jiwadja [Iwaidja] & $\begin{array}{c}\text { Jiwadja [Iwaidja] sea } \\
\text { chant }\end{array}$ & Oenpelli \\
\hline Side 5,6 & & Ubar [Wubarr] & Oenpelli \\
\hline Side 23,24 & Birds & - & Oenpelli \\
\hline Side $3,4.1$ & Tiwi & Tiwi mourning ceremony & $\begin{array}{l}\text { Snake Bay, Melville } \\
\text { Island }\end{array}$ \\
\hline Side $4.2,19.1$ & Wogaitj & Karaboga & Delissaville \\
\hline $\begin{array}{c}\text { Side } 7.1-2, \\
8,9.1\end{array}$ & Brinken & Tjarada [Tjarrarta] & Delissaville \\
\hline Side $7.3-4$ & Wogaitj & Mindarini [Mindirrini] & Delissaville \\
\hline $\begin{array}{l}\text { Side } 12.4, \\
13,14.1-2\end{array}$ & Brinken & Mindarini & Delissaville \\
\hline $\begin{array}{c}\text { Side } 9.2-3 \\
10,19.2\end{array}$ & Brinken & $\begin{array}{c}\text { Balga style song about } \\
\text { truck }\end{array}$ & Delissaville \\
\hline $\begin{array}{c}\text { Side } 11 \\
12.1-3\end{array}$ & Brinken & 'songs without dancing' & Delissaville \\
\hline $\begin{array}{c}\text { Side } 14.3 \\
15,16\end{array}$ & $\begin{array}{c}\text { Alandi, man from SW } \\
\text { Arnhem Land }\end{array}$ & $\begin{array}{l}\text { N. Central Arnhem Land } \\
\text { songs }\end{array}$ & Delissaville \\
\hline $\begin{array}{c}\text { Side } 17,18, \\
20\end{array}$ & Wogaitj & $\begin{array}{l}\text { Indi indi wonga [Nyindi- } \\
\text { yindi Wangga] }\end{array}$ & Delissaville \\
\hline Side 21,22 & Wogaitj (Mosek) & Mosek song & Delissaville \\
\hline
\end{tabular}

Source: Simpson, C. 1949, Aboriginal Music from the Northern Territory of Australia, 1948, with Annotations by Professor A. P. Elkin, (twelve 12-inch discs, PRX 2809-10, PRX 2645-52), Australian Broadcasting Commission (processed by Columbia Graphophone), Sydney. 
Six sides in all (discs 1, 3 and 12) contain material recorded in Oenpelli (total duration: approximately 15 minutes). The first disc (sides 1 and 2) contains a selection of public didjeridu-accompanied songs in a variety of languages and styles, while disc 3 (sides 5 and 6) contains recordings of the restricted Ubar (Wubarr) ceremony, which we will not discuss further here. Disc 12 (sides 23 and 24) contains bird calls - some recorded by Ray Giles at dawn on the lagoon at Oenpelli, described in Simpson's chapter 'The morning of the birds'. ${ }^{18}$

A relatively small amount of Tiwi material (about 10 minutes in all) is published in this recording on side 3 and the first cut of side 4 . From the account given of the recording session in Simpson's chapter 'Black opera', it seems that Ray Giles had a number of problems with his recording equipment that might have rendered some of the recordings unsuitable for publication. ${ }^{19}$ Simpson's ABC radio feature Island of Yoi also drew on this material. ${ }^{20}$ We will not discuss these recordings further here.

The Delissaville recordings constitute the bulk of Simpson's published collection: more than eight discs (sides 7-22 plus the second cut of side 4), constituting approximately 60 minutes of recorded sound. We will now discuss in more detail the known provenance of the various genres recorded at Delissaville.

First, we should explain that the term Wogaitj (also spelt Waugeit and Worgait) (from the Batjamalh word wagatj, meaning 'beach') generally referred to a grouping of people encompassing various language groups whose traditional country lay along the coast to the south of the Cox Peninsula, including speakers of Batjamalh, Kiyuk, Emmi/Mendhe and Marri Ammu/Marri Tjevin. Most residents of Delissaville, which was established on Larrakiya land in the 1940s, belonged to one of these language groups. ${ }^{21}$ The grouping term Brinken (Brinkin) was used to describe language groups whose traditional country lay further south-from the Moyle River south to the Fitzmaurice-including speakers of Magati Ge, Marri Ngarr and Murrinh-patha, amongst others. Some people from these groups were resident in Delissaville, but other relatives lived in Daly River and Port Keats (Wadeye), and to this day there continues to be frequent ceremonial exchange amongst and between these groupings. ${ }^{22}$

Many of the Delissaville recordings are of Wangga - a public didjeriduaccompanied dance-song genre associated with the Wagatj (and, to a lesser

18 Ibid., pp. 69-73.

19 Ibid., pp. 143-8.

20 Simpson, C. 1949, Island of Yoi, Radio Feature, first broadcast 18 January 1949, Australian Broadcasting Commission, Sydney. For a contents listing of the Tiwi field recordings, see Moyle, A Handlist of Field Collections of Recorded Music in Australia and Torres Strait, p. 216.

21 For further details, see Povinelli, E. 1993, Labor's Lot: The power, history, and culture of Aboriginal action, University of Chicago Press, Ill.; and Marett, A. 2005, Songs, Dreamings and Ghosts: The Wangga of north Australia, Wesleyan University Press, Middletown, Conn. 
extent, Brinkin) language groups. Each language group held one or more named repertories composed and performed by known songmen for various public ceremonies. ${ }^{23}$ Simpson's Delissaville recordings include extensive coverage of Wangga songs performed at a Karaboga 'final mourning' ceremony (side 4, cut 2, and side 19). This event, described in Simpson's chapter 'So Mabalang will lie down', formed the basis of the ABC feature Delissaville: Death rite for Mabalung. ${ }^{24}$ Such ceremonies - performed to dispose of the belongings of the deceased person some time after their death - continue to be performed today, and later in this chapter we give a detailed analysis of various aspects of this performance.

The songs used in the Karaboga ceremony are from the Nyindi-yindi Wangga repertory today associated with the Burrenjuck family. The same repertory is performed in the Indi-indi 'trade' corroboree songs (sides 17-18 and 20). Several Wangga-style songs by the renowned dancer and composer Mosek were also recorded by Simpson (sides 21-22); according to Elkin's notes, one song composed by Mosek was received by him from the snake spirit of the waterhole Belyuen (after which the present-day community is named), and another was later given to Simpson by Mosek, probably in exchange for tobacco. ${ }^{25}$ Mountford also recorded two Wangga songs on his trip to Delissaville; he too recorded Mosek (also known as Manbira or Manpurr) singing a song for Baluin (Belyuen) waterhole (Mountford, song 1), as well as the above-mentioned 'Winmala' song (song 2).

The Mindarini (Mindirrini) initiation chants (side 7, cuts 3-4; sides 12-13; side 14, cuts 1-2) recorded by Simpson-both from Belyuen residents and from visiting Brinkin performers - belong to a large pan-regional ritual complex (variously named 'naitpan', 'dingirri', 'kudjingka' or 'mandayala') that originates to the south, in the desert. ${ }^{26}$ These songs are partially restricted and will not be discussed further here.

Two other genres recorded at Delissaville by Simpson from Brinkin men are the Tjarada (Tjarrarta) 'love magic' songs (sides 7-8; side 9, cut 1) and a Balga-style song cycle about a trip in a motor truck (side 9, cut 2; side 10; and side 19, cut 2). Like Mindirrini songs, Tjarrarta songs also originate in the desert (according to Mountford, these songs had been learned by a Delissaville resident when he was working at Newry Station in the eastern Kimberley). ${ }^{27}$ In different areas,

\footnotetext{
23 Ibid.

24 Simpson, Adam in Ochre; and Simpson, Delissaville.

25 See Elkin's notes, in Simpson, Aboriginal Music from the Northern Territory of Australia, pp. 6-7. See also Simpson, Adam in Ochre, pp. 171-2.

26 Keen, I. 1994, Knowledge and Secrecy in Aboriginal Religion, Clarendon Press, Oxford, p. 142; Stanner, W. E. H. 1963 [1989], On Aboriginal Religion, Oceania Monograph 11, University of Sydney, NSW, p. 108. 27 See C. P. Mountford, 1948, Field Notes, p. 91, SLSA, and recorded explanation for cut 2: 'The Charada (1)' on disc 4, side 2 of Mountford, American-Australian Scientific Expedition to Arnhem Land 1948.
} 
Tjarrarta songs may be kept more or less secret from the opposite sex, and they exist in both men's and women's versions. ${ }^{28}$ There is no information in Simpson's book or Elkin's notes to suggest how private or otherwise these performances might have been, though Elkin notes that women were allowed to clap along with these songs. Of more certain public status is the song set about a trip in a motor truck (side 9, cut 2; side 10; and side 19, cut 2), which belongs to the Balga public genre (accompanied by either clap sticks or boomerang clap sticks) performed throughout the Kimberley region and traded into the Daly-Fitzmaurice region. ${ }^{29}$ Like Wangga, Balga songs are individually composed songs used for public ceremony. There is a notable difference: unlike Wangga, Balga songs are commonly performed by mixed groups of men and women (though it seems that the group recorded by Simpson was entirely male). The Brinkin songs without dancing (side 11) also appear to be in Balga style, although this is not mentioned explicitly in the notes.

Mountford also recorded the Tjarrarta and Balga genres (songs 5 and 6, the Tjarada; and song 4, Bulga). Mountford's recording of a non-secret ritual song variously termed Djuraman, Duralamin or Djuralam (song 3) also appears to be in Balga style (that is, with cyclical isorhythmic text, and accompanied by clap sticks). ${ }^{30}$ There are other correspondences with the Simpson recordings. Mountford's 'Song of the waterhole Balyuin by Manbira, a Worgeit man' ('Port Darwin Songs', cut 1) is the same song published in a different performance by Simpson (side 21, cuts 1-2) as 'Mosek's song' (Mosek's Aboriginal name was 'Manpurr', transcribed by Mountford as 'Manbira'). These similarities evidently arise from the same songs having been offered to visiting researchers on different occasions.

Finally, Simpson's recordings include a number of north-central or North-East Arnhem Land clan songs (Manikay) (side 14, cut 3; sides 15, 16) recorded from a Delissaville resident who, according to Elkin's notes, had been transferred there on parole from south-west Arnhem Land. ${ }^{31}$

Let us take a moment to reflect on the sources of the various songs recorded at Delissaville by Simpson and Mountford. We have at least two genres (Tjarrarta and Mindirrini) that originate in desert country far to the south, two or three

28 Berndt, R. M. 1976, Love Songs of Arnhem Land, Thomas Nelson, Melbourne.

29 Barwick, L. 1998, 'The Kimberleys area', in A. Kaeppler and J. W. Love (eds), Encyclopedia of World Music (Oceania Volume), Garland Publishing, New York; Barwick, L. (Forthcoming), 'Musical form and style in Murriny Patha Djanba songs at Wadeye (Northern Territory, Australia)', in M. Tenzer and J. Roeder (eds), Analytical and Cross-Cultural Studies in World Music, Oxford University Press, Oxford, UK, and New York; and Moyle, A. M. 1968, Songs from the Kimberleys: Companion booklet for a 12-inch LP disc, cat. no. AIAS/13, Australian Institute of Aboriginal Studies, Canberra.

30 Mountford (1948, Personal Journal, p. 89, PRG 1218/17/12, Mountford-Sheard Collection, SLSA) has 'Djuraman'; the contents listing of the sound recordings have 'Duralamin'; and the anonymous female announcer on PRG 1218/17/55 pronounces the word 'Djuralam'.

31 See Elkin's notes to side 14, cut 3, on p. 5 of the notes to Simpson, Aboriginal Music from the Northern 
repertories of Balga, a genre originating in the Kimberley region to the southwest, and one Manikay repertory from the north-east. Even the Wangga genre owned and performed by Delissaville residents had its historical origins not on the Cox Peninsula but in the traditional country of most of its residents: the Daly region to the south of Delissaville. Indeed, several Wangga repertories are represented in the recordings. Simpson's aural snapshot of Delissaville in 1948 reflects a remarkable diversity of language, affiliation to country and ceremonial practice.

A similar picture of underlying social and geographical diversity is suggested by the provenance of the 11 public songs recorded by Simpson and Giles at Oenpelli. For example, of the four Oenpelli songs published by Simpson in Aboriginal Songs from the Northern Territory of Australia, 1948, none actually belongs to the country around Oenpelli itself. Two sea songs are from the north coast (side 1, cut 1 and side 2, cut 2). ${ }^{32}$ A Gunbalang (Kun-barlang) 'sweetheart' song (side 1, cut 2) originates from country to the north-west of Oenpelli, near Maningrida, ${ }^{33}$ while the Djauan (Jawoyn) trading and sweetheart song (side 2, cut 1) comes from country to the south of Oenpelli. ${ }^{34}$ Simpson recorded seven other public didjeridu-accompanied songs at Oenpelli, which are included in the ABC Radio Archives disc MA24; most of these are listed as unidentified Kunwinjku corroboree songs, tentatively identified by Iwaidja and Mawng informants in 2005 and 2007 as belonging to various public love-song or dancesong genres.

Seven of the 11 songs recorded by Simpson and Giles also appear, in a different order, in Mountford's Oenpelli Aboriginal Songs, discs PRX2716-[17] (PRG 1218/17/53-54, State Library of South Australia), and in a compilation disc probably prepared for a lecture by Mountford (PRG 1218/17/55, State Library of South Australia) (Table 18.2). Note that Simpson seems not to have provided Mountford with sound recordings of the restricted Wubarr songs he had recorded at Oenpelli, although members of the Expedition did film and photograph the ceremony (see Garde, this volume).

\footnotetext{
32 Although classified by Simpson's informants as 'Jiwadja' (Iwaidja) songs, these were identified by Iwaidja-speaking people in Minjilang in 2005 as probably a Nganarru song belonging to Manangkardi people and a Mirrijpu song belonging to Mawng people, both coming from Goulburn Island rather than Iwaidja country on the Cobourg Peninsula (Linda Barwick, field notes, 2005).

33 O'Keeffe, I. 2007, 'Sung and spoken: analysis of two different versions of a Kun-barlang love song', Australian Aboriginal Studies, vol. 2007, no. 2, pp. 46-62.

34 Merlan, F., Jacq, P. and Diwurruwurru-jaru Aboriginal Corporation 2005, Jawoyn Topic Dictionary (Thesaurus)/Compiled by Francesca Merlan \& Pascale Jacq, Diwurruwurru-jaru Aboriginal Corporation, Katherine, NT.
} 
Table 18.2 Correspondences between Simpson's Oenpelli recordings and Oenpelli songs in the Mountford-Sheard Collection

\begin{tabular}{|c|c|c|c|c|}
\hline Summary description & $\begin{array}{c}\text { Simpson } \\
1\end{array}$ & $\begin{array}{c}\text { Simpson } \\
2\end{array}$ & $\begin{array}{c}\text { Mountford } \\
\text { [Simpson] } 1\end{array}$ & $\begin{array}{l}\text { Mountford } \\
\text { [Simpson] } 2\end{array}$ \\
\hline $\begin{array}{l}\text { Iwaidja corroboree by } \\
\text { Kunwinjku men }\end{array}$ & Cut 1 & $\begin{array}{l}\text { Side } 1, \\
\text { cut } 1\end{array}$ & $\begin{array}{l}\text { Disc } 5, \text { side } 1, \\
\text { cut } 2\end{array}$ & $\begin{array}{l}\text { Side 2, cut } 5 \\
\text { (part 1) }\end{array}$ \\
\hline Unnamed [Kun-barlang] & Cut 2 & & $\begin{array}{l}\text { Disc } 5, \text { side 2, } \\
\text { cut } 2\end{array}$ & Side 2 , cut 2 \\
\hline Jawoyn sweetheart & Cut 3 & & & \\
\hline Jawoyn sweetheart & Cut 4 & $\begin{array}{l}\text { Side } 2, \\
\text { cut } 1\end{array}$ & & \\
\hline Iwaidja saltwater fish & Cut 5 & $\begin{array}{l}\text { Side 2, } \\
\text { cut 2 }\end{array}$ & $\begin{array}{l}\text { Disc } 6 \text {, side } 1, \\
\text { cut } 1\end{array}$ & $\begin{array}{l}\text { Side 2, cut } 5 \\
\text { (part 2) }\end{array}$ \\
\hline $\begin{array}{l}\text { Sweetheart gossip song } \\
\text { [Kun-barlang] }\end{array}$ & Cut 6 & $\begin{array}{l}\text { Side } 1, \\
\text { cut } 2\end{array}$ & $\begin{array}{l}\text { Disc } 5, \text { side } 1, \\
\text { cut } 1\end{array}$ & Side 2 , cut 4 \\
\hline Kangaroo Gulawubarra & Cut 7 & & $\begin{array}{l}\text { Disc } 5, \text { side 2, } \\
\text { cut } 1\end{array}$ & Side 2 , cut 1 \\
\hline Kunwinjku corroboree 1.1 & Cut 9 & & $\begin{array}{l}\text { Disc 5, side 2, } \\
\text { cut } 3\end{array}$ & Side 2 , cut 3 \\
\hline Kunwinjku corroboree 1.2 & Cut 10 & & $\begin{array}{l}\text { Disc } 6, \text { side } 1, \\
\text { cut } 2\end{array}$ & \\
\hline Kunwinjku corroboree 2.1 & Cut 11 & & & \\
\hline Kunwinjku corroboree 2.2 & Cut 12 & & & \\
\hline
\end{tabular}

Notes: 'Simpson 1' refers to the ABC Radio Archives disc MA24; 'Simpson 2' refers to Simpson, C. 1949, Aboriginal Music from the Northern Territory of Australia, 1948, with Annotations by Professor A. P. Elkin, (twelve 12-inch discs, PRX 2809-10, PRX 2645-52), Australian Broadcasting Commission (processed by Columbia Graphophone), Sydney; 'Mountford [Simpson] l' refers to Mountford, C. P. [Simpson, C.] 1949, Oenpelli Aboriginal Songs, (two 12-inch discs, PRX2716 and FXS188 [PRG 1218/17/53-54, State Library of South Australia]), Columbia Graphophone, Homebush, NSW; and 'Mountford [Simpson] 2' refers to C. P. Mountford [Simpson] 1960, Aboriginal Songs of Delissaville, Oenpelli and Groote Eylandt, (one instantaneous 12-inch disc, compilation of previous recordings with spoken annotations, probably prepared for lecture presentations), PRG 1218/17/55, State Library of South Australia.

We can trace various reasons for the musical and linguistic diversity evidenced by these musical snapshots of Delissaville and Oenpelli. Each of these communities actually brought together people from a number of different language groups, providing a rich multilingual social fabric in which marriage laws maintained diversity by demanding that people married outside their own clan or language group. So the Wangga songs performed by Belyuen (Delissaville) residents still celebrate today, in their ancestral languages, their traditional country to the south, as well as creating ongoing attachments to their current residence through the sacred waterhole Belyuen (the inspiration for Mosek's song recorded by both Mountford and Simpson). Ceremonial exchange, too, has been - and continues to be - a means of maintenance and transmission 
of diversity. Wangga singers from Belyuen have been in constant demand to perform at circumcision ceremonies, funerals and other public events in Darwin and throughout the Top End, and Belyuen is visited in return by performance groups from Katherine, Beswick, Daly River and Wadeye. The Mindirrini songs are associated with a pan-regional ceremonial complex that tied together people across a large area of the Top End by regular visits to each other's country to perform ceremonies. On such occasions, more secular songs (such as Wangga or newly composed repertories such as the Brinkin truck song) may be performed and traded in addition to the sacred ceremonial songs. Delissaville residents working on cattle stations in the Kimberley formed relationships with other groups holding Tjarrarta and Balga songs, trading songs and perhaps brokering marriages and other social connections. Each of these groups in turn might hold songs that had been traded to them from yet further away. Finally, movements of individuals from one multilingual community to another might be motivated by any number of other extraneous social factors, including parole placements and work obligations.

In the course of the Barks, Birds \& Billabongs symposium, it became clear that the 1948 Expedition provided a locus for interactions between Aboriginal and non-Aboriginal people - not just in 1948 but continuing right up to the present through the numerous records and outputs of the Expedition. Martin Thomas, for example, uncovered previously unseen dimensions of the Expedition in a series of recorded conversations in 2007 with Gerald Blitner, one of the guides and interpreters employed by the Expedition while it was on Groote Eylandt (see Thomas, this volume). Bruce Birch presented a local Indigenous story about mammalogist David Johnson's time at Cape Don and his solo walk to Oenpelli. This account included many elements not recorded by Johnson himself, including an encounter with a yumbarrbarr (a supernatural giant) at Port Essington on Cobourg Peninsula and, more remarkably, an encounter with the spirit of the man Marrarna, whose remains lay in a cave at Dilkbany, a dangerous kuyak or 'sickness' site north of Oenpelli (see Birch, this volume). Later in our chapter, we will briefly explore another contemporary interaction (from 2008), which occurred in ceremony between Marett and the son of one of the main dancers in the ceremony recorded by Simpson in 1948.

But first of all let us give some further details about the ceremony that was recorded by Simpson at Delissaville in 1948 and discussed in his book Adam in Ochre and the ABC documentary feature Delissaville: Death rite for Mabalung. ${ }^{35}$ We will consider some problematic aspects of his account before comparing it with a version of the same ceremony performed in 2008 by the descendants of the people who performed 60 years earlier. 
The ceremony recorded by Simpson at Delissaville in late September or October 1948 was a Kapuk or Karaboga ceremony, also known in English as a 'ragburning' or 'burnim rag' ceremony. We know from numerous subsequent ethnographic accounts that the main purpose of this ceremony is to conduct the spirit of a deceased person away from the society of the living and into the society of the dead. This is done by burning the belongings, or 'rags', of the deceased in order to drive the spirit into the open and then conducting it away from the living through the performance of appropriate songs and dances. Marett recently described it as follows:

In Songs, Dreamings and Ghosts I identified a number of functions for this ceremony: the removal of the pollution associated with death; the freeing of the spirit of the deceased from its attachment to the living; the comforting of those left behind; the enactment of reciprocal ceremonial responsibilities between different language groups; and the nurturing of a particular relationship between humans and the land, the latter of which is conceived of as living, sentient and the source of all human life... ${ }^{36}[\mathrm{~W}]$ hen you burn a person's 'rags', his or her spirit, which at death has taken refuge in these particularly cherished belongings, is driven out by fire. Thus liberated, the spirit of the deceased must then be persuaded or coerced - the relative degree of coercion or persuasion depends a great deal on the character the deceased had when alive - to leave the company of the living and join the society of the dead, who are known variously (according to language) as walakandha, ma-yawa, ngutj or wunymalang. The way this is done is to sing the worlds of the living and the dead into alignment so that the deceased may cross over from one to the other. Living songmen, singing songs that have been given to them in dreams by their ancestral dead (who in many cases are their own deceased fathers), create a liminal space where the worlds of the living and dead interpenetrate. Dancing (where the living dance as the dead and the dead as the living) and other forms of ritual actions also assist. ${ }^{37}$

The primary deficiency of Simpson's account of the 1948 Kapuk was that to some degree he mistook the purpose of the ceremony, and this misapprehension rested on a mistaken view of the wunymalang (what he referred to as 'wingmalung') spirits that formed the focus of the ceremony. Simpson, who was a journalist not a professional ethnographer, relied heavily on the testimony of the superintendent

36 Marett, Songs, Dreamings and Ghosts, pp. 60-9.

37 Marett, A. 2010, 'Vanishing songs: how musical extinctions threaten the planet', Ethnomusicology Forum, 
of the Delissaville settlement, Tom Wake. This is particularly clear in the part of the $\mathrm{ABC}$ radio documentary Delissaville: Death rite for Mabalung in which they discuss wunymalang:

TOM WAKE: The old man has now laid down on the blanket and the damper, which has been surrounded by some gifts. The idea of this is to absorb the evil spirit which caused the sickness of this girl and her death. He will get this sickness now, and then the man who is singing and the doctor blackfella will sing him better...The idea of [the] doctor blackfella, who is now marching around the arena, peering, gesturing, looking in all directions, is to try and round up and frighten or shepherd the wingmalung or malignant spirits into the man who is lying under the gifts and clothes. The reason for this is that the spirits, or wingmalung, are now aware that it is an old man that they have gone into, and therefore they want to leave him because an old man is of no use to them.

COLIN SIMPSON: The malignant spirits, forced to leave the dead woman's clothes when the clothes were burnt, flew into the gift materials, and finding a man in the midst of the gifts transferred themselves to him. But he's an old man. He'll die soon anyway and they can't get out because they're being kept inside by the magic gestures of Mosek, who is also a duworrabuk [Batjamalh, dawarrabörak]. But the wingmalung are still fierce and fighting and even for such a famous duworrabuk as Aliong the old man, they can make it very uncomfortable. ${ }^{38}$

Wake and Simpson characterise the 'wingmalung' as the malignant spirits that first caused the death of the young woman, Mabalung (written as Mabalang by Simpson), and then infected her belongings, from which they need to be exorcised by various ceremonial acts. It is as though wunymalang were some sort of pestilential agent - analogous perhaps to the Tuberculosis bacillus that, according to Western medicine, killed the young woman-but this is quite wrong. The wunymalang that provides the focus of the ceremony is in fact the spirit of the deceased. It is the form that the conception dream or maruy aspect of her being takes after death. ${ }^{39}$ In the course of the ceremony, songs that have been given to a living songman by wunymalang are sung and living humans dance as wunymalang; indeed, the ceremony is about drawing the wunymalang dead into an intimate though temporary interaction with the living. This is what allows the spirit of the deceased to pass over into the company of the wunymalang dead. What the ceremonial performers are dealing with therefore is not some invasive pestilential agent, but the spirit of the deceased and the broad

38 Transcript from the sound recording by Allan Marett, December 2009. We preserve the spellings used in Simpson, Adam in Ochre.

39 See further Marett, Songs, Dreamings and Ghosts, p. 67. 
company of the dead. True, the young woman's wunymalang could become malignant if the proper ceremonies are not performed in a timely way, and the other wunymalang that are invoked by the ceremony could become dangerous if not handled properly, but wunymalang are not inherently malignantdangerous perhaps, but unless provoked in some way, not malignant. Most importantly, what Wake and Simpson failed to recognise in their account is that the focus of the ceremony is the young woman herself, not random demonic forces. Moreover, any suspicion that the account given by Wake and Simpson represented some older, now lost understanding of the nature of wunymalang and their role in the ceremony is repudiated by accounts of Kapuk ceremonies in the Delissaville community in the period immediately preceding and following the ceremony witnessed by Simpson. Writing of a ceremony performed two years earlier, A. P. Elkin makes it clear that the deceased's spirit is the focus of the ceremony:

In 1946 I was present at a Delissaville corroboree: the Songman sang of his deceased wife: her spirit was reported in the song as saying that she was now finished (with the surroundings of the camp) and was going away. In the dance the men swayed gracefully and rhythmically...it was a swaying action - the action of a spirit, or 'shade' moving back and forth in the wind. ${ }^{40}$

Describing a Kapuk ceremony that took place at Delissaville some four years later than the one Simpson witnessed, Elkin again makes clear that we are dealing primarily with the spirit of the deceased, not with a host of malignant forces: 'an elder lies across the hole into which the ashes have been scraped and is covered with a rug so that the spirit can pass from the destroyed articles into him. ${ }^{41}$

Another shortcoming of Simpson's account lies in its failure to grasp the significance of the kinship relationships between the ceremonial participants. This might have been a shortcoming of the Expedition as a whole, since Mountford has been criticised-not only by later commentators, but by his own contemporaries (such as Elkin) - for his failure to adequately record the kinship relationships of the artists whose work he collected. Philip Jones in this volume sees positive benefits flowing from this practice, in that it gave the artworks in Mountford's collection an autonomy that provided a foundation for the future development of the Aboriginal art movement, free of the 'relatively arcane data concerning kinship and social relations' (Jones, this volume). But there is a price to be paid when artistic products and processes are stripped of their original significance and are imbued with new meanings. In the case

40 Elkin and Jones, Arnhem Land Music, p. 153.

41 Ibid. 
of the ceremony under consideration here, what Simpson failed to realise is that Kapuk ceremonies are very much family affairs. They are conducted for the family of the deceased, and the ceremonial participants all stand in strict kinship relationships to the deceased and one another. With the help of living members of the Belyuen community, we have been able to identify most of the key players in the 1948 ceremony and to establish their kinship relationships. The relationships set out in Figure 18.1 have been reconstructed by Barwick from a variety of sources including names and relationships mentioned in Simpson's account of the ceremony, put together with genealogical information collated by Marett and Barwick during their fieldwork at Belyuen.

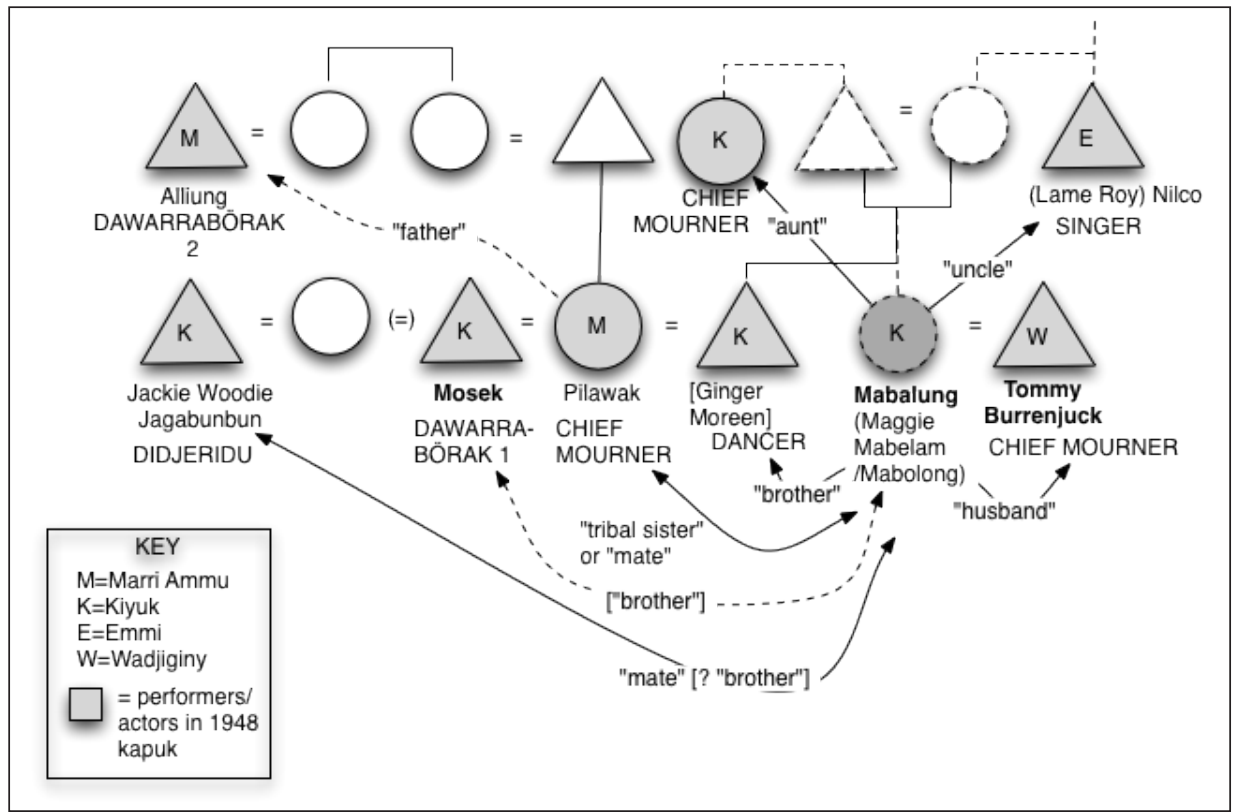

Figure 18.1 Relationships between the principal participants in the Karaboga ceremony, 1948

From Figure 18.1, we can see that the principal mourners for the deceased woman, Mabalung (Mabalang in Simpson's rendering, also known in other records as 'Maggie Mabelam' and 'Mabolong'), are her husband, Tommy Burrenjuck ('Burrajuk' in Simpson's rendering; Marett uses his original Aboriginal name, Barrtjap), and Pilawak (rendered 'Billawauk' by Simpson), wife of Mabalung's brother, Ginger Moreen, together with an unnamed aunt of the deceased. The deceased's husband, Tommy Barrtjap, was the principal songman and ceremonial leader at Belyuen/Delissaville until his death in the early 1990s. He was recorded by Elkin, by Alice Moyle and by Marett over a period of more than three decades, and his repertory forms the focus of a chapter in Marett's book Songs, Dreamings and Ghosts. ${ }^{42}$ Pilawak went on to 
become one of the key ceremonial women at Belyuen. Marett saw her taking a leading role in a rag-burning ceremony held at Nadirri in 1988. Pilawak's other husband, Mosek Manpurr, was one of the two dawarraböraks (rendered as 'duworrabuk' by Simpson) or 'doctor blackfellas' officiating at the ceremony. The other dawarrabörak was Alliung (rendered as 'Aliong' by Simpson), who stood in the classificatory relationship of 'father' to the deceased. The singer was Lame Roy Nyilco (Nilcoo), who stood in the correct relationship of 'mother's brother' to the deceased.

Having dealt with some of the problems with Simpson's account, let us turn to some of the significant similarities and differences between the 1948 Kapuk and a Kapuk performed very recently - in 2008 - for members of the same family, since the latter not only sheds light on the former, but also shows the extent to which the traditions described by Simpson continue today. Figure 18.2 summarises the relationships of the participants in the 2008 ceremony. The key to the relationship between the two ceremonies is Tommy Barrtjap. The 1948 ceremony was for his second wife, Mabalung; the 2008 ceremony was for Tommy Barrtjap's eldest son and principal heir to his song tradition, Kenny Burrenjuck. Kenny was the son of Tommy and his third wife, Mabel Muluk (daughter of another great Belyuen songman Jimmy Muluk). The ceremony was organised by Tommy's fourth wife, Esther (the daughter of another leading songman Nym Mun.gi). This ceremony was even more of a family affair than the 1948 ceremony, in that Kenny's brother, Timothy, was one of the two singers, but Timothy felt aggrieved at having to sing for his brother: the relationship was too close. The other singer was Marett, who by then had been singing with Kenny for a number of years.

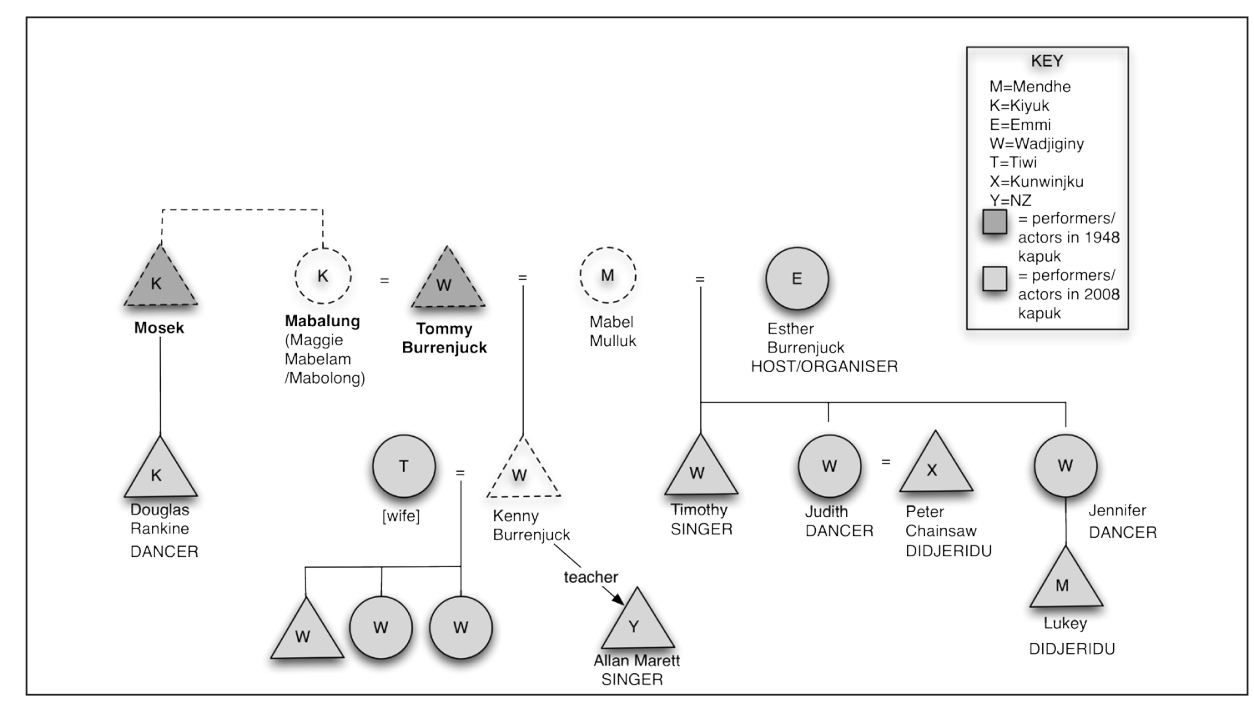

Figure 18.2 Relationships between the participants in the ceremonies in 1948 and 2008 
As happened in 1948, the 2008 ceremony was conducted near the house of the family. In 1948 it was beside the hut of Tommy Barrtjap: 'The site for the ritual... is close to the ripple-iron hut of Burrajuk, the widower, where Mabalang lived. ${ }^{\prime 43}$ In 2008 the ceremony ground was constructed beside Esther Burrenjuck's house at the community of Fifteen Mile, on the outskirts of Darwin. This was not where Kenny lived (he had made his home for many years at Milikapiti-Snake Bay - on Melville Island), but it was one of the main residences of his patrilineal family, most of whom live at Belyuen or Fifteen Mile. It is common practice on the Daly River to perform ceremonies of this type either on the country of the deceased (this pattern is more common at Wadeye, where people have easier access to their country) or near the dwelling of the deceased's family (this has been the standard practice at Belyuen for more than half a century, because the country of most groups at Belyuen is far distant and relatively inaccessible).

The structure of the ceremony ground in 2008 was very similar to that in 1948 . Basically, an area roughly in the shape of a square was enclosed by stretching cord between four posts located at each corner of the square. In 1948 the posts were made of rusty pipes and the cords were 'strong bush vine' ${ }^{44}$ Nowadays, the posts are usually made from cut saplings, and the cords or wire bought at a local shop. This was the case for the 2008 Kapuk. A hole is dug in the centre of the ground and kindling placed nearby. At Delissaville in 1948 and at Fifteen Mile in 2008 (and indeed in numerous other Kapuk ceremonies that we have witnessed at Belyuen) the belongings of the deceased are burnt outside the hole and then the ashes are pushed into the hole before it is filled in. In more southern Daly communities such as Wadeye, the belongings are put into the hole and set alight. This might be an innovation that derives from the availability of kerosene to ignite the fire. Whereas in 1948 spears and pearl-shell pendants were placed beside or on the corner posts, this was not the case in 2008, though it is not uncommon for spears to be located thus in modern ceremonies.

Let us turn now to the music and dance. As we have already said, the singer in 1948 was Lame Roy Nyilco ('Nilcoo'). A notable and unusual feature of this ceremony was that the same song was sung over and over throughout the whole ceremony. Typically Kapuk ceremonies use a variety of songs; the 2008 Kapuk, for example, used five different songs. At this distance in time, one can only speculate why this was the case. Perhaps Lame Roy Nyilco was not a very experienced singer; he is certainly not mentioned as a singer in any other records. In a work of popular non-fiction, John K. Ewers recorded that in 1947 the two main singers at Delissaville were Buntuck (Tommy Barrtjap's 'father' father's brother-Jimmy Bandak) and Argok (Aguk Malvak, the father's brother

43 Simpson, Adam in Ochre, p. 173.

44 Ibid. 
of another of the later Belyuen singers, Bobby Lambudju Lane). ${ }^{45}$ Who knows why Jimmy Bandak did not perform for the Kapuk of his 'son' Tommy Barrtjap's wife. Perhaps he was simply elsewhere or perhaps he was deemed to be too close a relation. As already noted, in 2008 Timothy Burrenjuck complained vociferously on precisely these grounds at having to sing Kapuk for his brother, Kenny, and such matters were almost certainly observed more strictly in 1948.

Turning to the song itself, consultation with members of the Belyuen community suggests that the text is made up mainly of untranslatable vocables, which are regarded as the untranslated language of wunymalang spirits (since these are the spirits who give songmen songs in dreams). The vocables are interspersed with a few words in Batjamalh, including perhaps nga-ve (I go). Although this song is no longer sung - and indeed does not reappear in any of the later recordings of songs from Belyuen - it has many of the key characteristics that typify the Nyindi-yindi Wangga repertory owned and performed by the Burrenjuck family. The song is very similar (though not identical) to the song Nyere-nye Bangany-nyaya that Marett recorded Tommy Barrtjap singing in 1988, and which was also performed by Timothy Burrenjuck and Marett in the 2008 Kapuk. The similarities are striking.

The melodies of the two songs are almost identical and conform to the dorian series with an unstable third (C-D-E-flat/E-F-G-A-B-flat-C) that is typical of the Nyindi-yindi repertory. ${ }^{46}$

The structure of both songs consists of a series of vocal sections ${ }^{47}$ (two in the case of the 1948 and 2008 recordings; four in the 1988 recording), followed by a coda, where the singer performs not text but didjeridu mouth sounds. ${ }^{48}$ This last feature is almost unique to the Nyindi-yindi repertory.

Each vocal section consists of one or two melodic sections in which the text is sung isorhythmically, followed by a final melismatic vocal section. ${ }^{49}$ Five other of Barrtjap's songs conform to this pattern. ${ }^{50}$

As mentioned above, the isorhythmic text sung in each vocal section comprises a mixture of vocables and Batjamalh words. The rhythm to which the isorhythmic text is performed is very similar in both performances.

45 Ewers, J. K. 1954, With the Sun on My Back, (Second edition), Angus \& Robertson, Sydney, p. 25.

46 Marett, Songs, Dreamings and Ghosts, p. 158.

47 For a definition of 'vocal section', see ibid., pp. 18, 87-8 and passim.

48 'Didjeridu mouth sound' is a term coined by Alice Moyle to describe the vocalisation of didjeridu rhythms, often performed by a singer to indicate the next song's accompaniment rhythms to the didjeridu player; see Moyle, Songs from the Northern Territory.

49 For a definition of 'melodic section', see Marett, Songs, Dreamings and Ghosts, pp. 87-8 and passim.

50 See further ibid., pp. 174-5. 
Each vocal section is accompanied by either fast, uneven quadruple beating or fast doubled beating (see Figure 18.3). ${ }^{51}$ In the 1948 song, the first vocal section uses fast, uneven quadruple beating and the second vocal section and coda use fast doubled beating. In the 1988 performance of Nyere-nye Bangany-nyaya, the order is reversed: the first two vocal sections use fast doubled beating, and the third, fourth and coda use fast, uneven quadruple beating. In Timothy Burrenjuck and Marett's performance of Nyere-nye Bangany-nyaya in the 2008 Kapuk, fast, uneven quadruple beating was used throughout, but alternation between the two rhythmic modes was used for other songs belonging to the group of five mentioned in point 3 above.

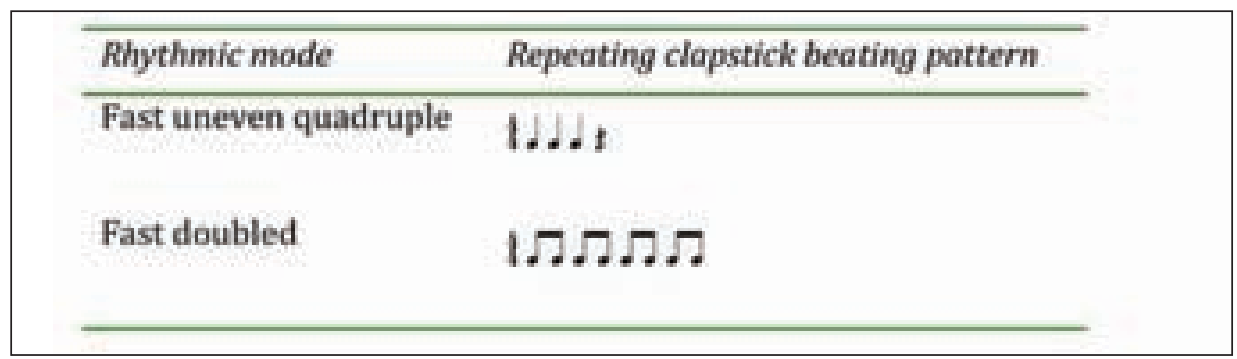

Figure 18.3 Repeating clap-stick beating patterns associated with the two rhythmic modes used in Nyilco's song

We can safely conclude that the song performed for the 1948 Kapuk belonged to the Nyindi-yindi repertory of the Burrenjuck family ('Barrtjap's Wangga'). ${ }^{52}$ Although the particular song performed by Nyilco appears not to have survived in the present-day repertory, it is clearly closely related to Barrtjap's Nyere-nye Bangany-nyaya.

Another key difference between the 1948 ceremony and that held in 2008 concerns the structure of the ceremony. In 1948, the ceremony clearly fell into two parts. In the first, the belongings of the deceased were burnt and the ashes interred. In the second, a native doctor, or dawarrabörak, Alliung, lay on the filled-in hole where the ashes were interred and was covered with a blanket. During this phase of the ceremony, Alliung also ate damper into which some of the ashes had been mixed. The point of this was to attract any residual power of the wunymalang spirit of the deceased woman into a spiritually powerful man, thereby protecting less powerful members of the community from any malicious intent the spirit might have. At the same time, the other dawarrabörak, Mosek, performed a grotesque dance that articulated some of the key properties of a wunymalang.

51 For a description of the rhythmic modes of Wangga, see ibid., pp. 203-6.

52 Ibid. 
It is clear from Elkin's account that the two-part form of the ceremony was still being practised in $1952 .{ }^{53}$ At some time prior to the 1980s, however, the second part of the ceremony was discontinued. We have been told that the reason for this was that after Alliung and Mosek died, there were no more dawarraböraks at Belyuen with the power to carry it off. Certainly, we have never witnessed this part of the ritual, though elements of it survive. Marett has seen Frank Dumoo, the ritual leader for Wangga at Wadeye and the southern Daly, lying on the ground during a Kapuk and it has been reported that he sometimes also ceremonially eats damper on the dance ground. Even without this second part of the ceremony, however, circumspection about the power of the wunymalang persists in the truncated ceremony seen today. Normally, more senior men are the ones who first dance on the filled-in fire hole. Only later are the more vulnerable younger men and boys allowed onto this area. Indeed, in the 2008 Kapuk, some young boys initially rushed forward to dance on the hole just after it had been filled in, but they were quickly and quite roughly pushed away by the older men.

Yet another element of this ceremony might have survived from the now defunct second part, and some of its significance might, to some extent, rely on Simpson's description of the 1948 ceremony. At the very end of the 2008 ceremony, Douglas Rankin, the son of Mosek Manpurr (one of the two 1948 dawarraböraks), announced that he wanted to dance. At that point, Marett was the principal singer, and Rankin danced directly and powerfully towards him, performing the grotesque movements associated with wunymalang - the sorts of movements that were described by Simpson as follows: 'He's a bent old man, a grotesque-looking figure...coming forward with stiff jerky movements. His eyes have a trance-like gaze in them...he holds out his crooked hands and then withdraws them. ${ }^{.54}$

We are not suggesting that Rankin learnt to dance like this from hearing Simpson's recordings. It is more likely that as a young man he witnessed his own father and perhaps other dawarrabörak dancing like this. But his decision to dance up to Marett in that way at the end of the Kapuk probably rested on his knowing that Marett knew precisely what he was invoking-namely, the dawarrabörak dance. And the reason for this is because he knew about Simpson's $\mathrm{ABC}$ program, which has been lodged on a computer at the Belyuen Community 'Bangany Wangga' archive and widely circulated among community members in the form of CDs. And he knew that Marett also knew this program. That was the link that made this performative moment significant.

53 Elkin and Jones, Arnhem Land Music, p. 173.

54 Simpson, Adam in Ochre, p. 179. 
We spoke earlier about the ways in which elements of the 1948 Expedition have continued to provide a locus for the generation of new stories and narratives. At Belyuen, it seems that Simpson's recordings and explanations probably played a part in generating the shared understandings that gave significance to Douglas Rankin's dance. The examples we cited earlier were primarily narrative in nature. In Aboriginal culture, however, dance is a more powerful but perhaps less easily accessed enactment of knowledge, and it behoves us to remain alert to such articulations of knowledge about the earlier recordings and other documents that are now the shared legacy of both Aboriginal and non-Aboriginal people.

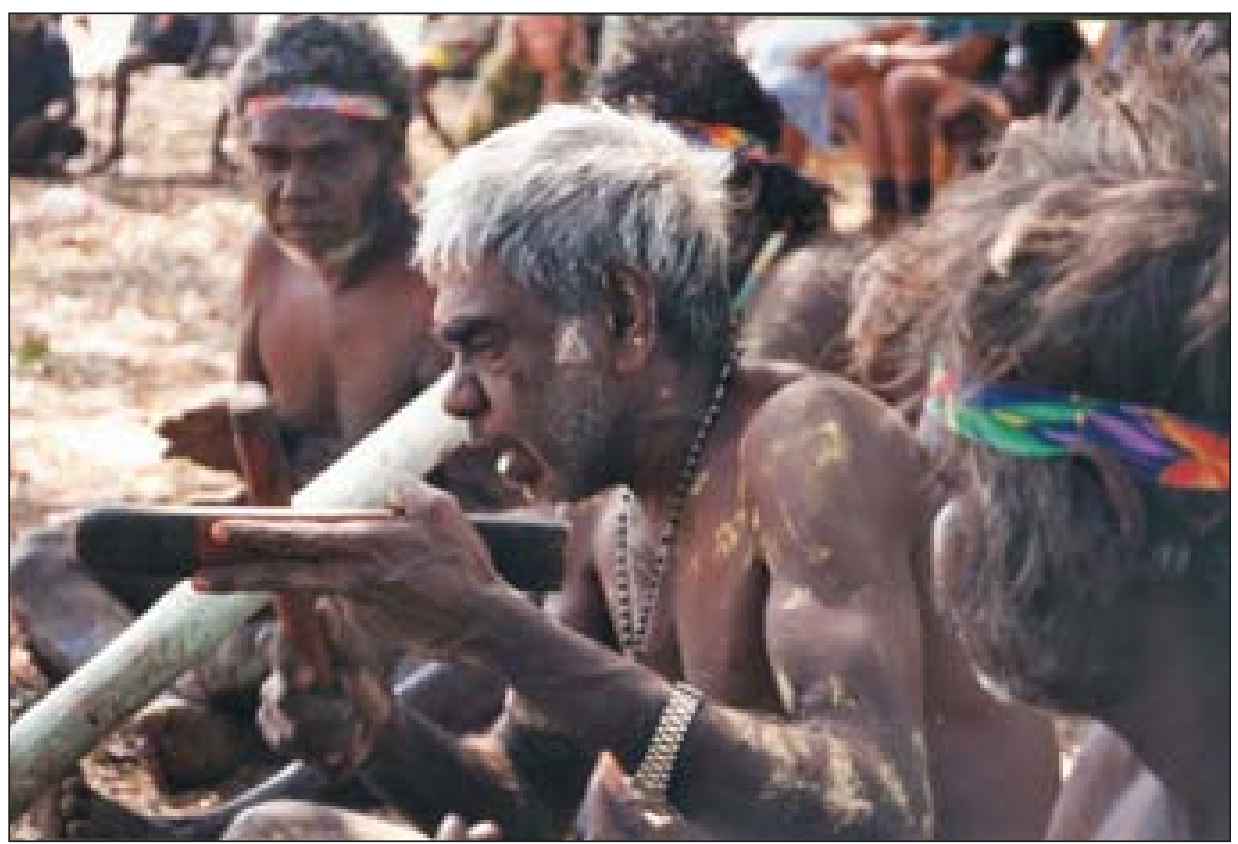

Figure 18.4. Kenny Burrenjuck singing Wangga at Belyuen, 1997

Photograph by Linda Barwick 